\title{
THE EFFECT OF EPINEPHRINE ON THE VOLUME OF THE BLOOD
}

\author{
By NOLAN L. KALTREIDER, GEORGE R. MENEELY, AND JAMES R. ALLEN \\ (From the Department of Medicine, University of Rochester School of Medicine and Dentistry, \\ and the Medical Clinic of the Strong Memorial and Rochester Municipal \\ Hospitals, Rochester, New York)
}

(Received for publication January 17, 1942)

A previous investigation (1) has shown that as a result of a sudden rise in the venous and arterial pressures by exercise there is a prompt and definite decrease in the plasma volume: Further, moderate exertion is accompanied by a proportionate diminution in the blood volume, since the volume of the cells remains essentially the same. Only when the physical activity is severe are new cells added to the circulating volume. During the recovery period, the volume of the blood gradually returns to the resting value. It was suggested that the elevated capillary pressure produced by exercise caused increased filtration of fluid through the capillary walls, which in turn leads to a decrease in the plasma volume, and that the slight increase in cell volume during severe exercise was a result of extrusion of cells from the blood depots into the circulating blood. It was suggested that the latter was mediated through the symphathicoadrenin mechanism.

If these factors are responsible for the alterations in the volume of the blood during exhaustive exercise, the administration of epinephrine might be expected to produce a similar picture, since this drug increases the systemic pressure and contracts the blood depots. The purpose of this communication is to report the observations of the blood volume before and after the subcutaneous injection of epinephrine in normal individuals, in patients with splenomegaly, and in 2 subjects whose spleens had been removed following rupture.

\section{METHODS AND MATERIAL}

The methods employed in this investigation were the same as those described previously (1). All experiments were carried out under basal conditions. On coming to the laboratory in a post-absorptive state the subject rested in a horizontal position for 60 minutes. The azo blue dye ( $T-1824)$ was then injected intravenously and the disappearance slope for the calculation of the initial plasma volume was determined over a period of $40 \mathrm{~min}$ utes. By this method, changes in the plasma volume in excess of +40 cc. and -90 cc. may be considered significant (1). Blood was also taken at intervals for cell volume, hemoglobin, and serum protein determinations. The blood and cell volumes were obtained from the plasma volume and the hematocrit value. The control venous pressure and circulation time were then measured. Immediately after the control data were obtained, from 0.8 to $1 \mathrm{cc}$. of epinephrine (1-1000) was administered subcutaneously. Blood for serum samples and hematocrits was withdrawn from the ante-cubital vein at appropriate intervals after the injection of the drug. From the initial plasma volume and the deviation of the dye concentration of these samples from the prolongation of the disappearance slope, changes in the plasma volume were calculated. At varying intervals during the experimental period, the venous and arterial pressures and the circulation time were determined.

The above procedure was carried out on 5 young subjects with normal cardiovascular systems and one subject who was in good condition save for chronic rheumatoid arthritis. In addition studies were made on 2 individuals with polycythemia vera and on 2 normal subjects whose spleens had been removed one year previously because of an accidental injury. Prior to this study, the patients with polycythemia had been subjected to repeated therapeutic phlebotomies during a period of several years. Both subjects had palpable spleens.

\section{RESULTS}

Normal subjects. The changes noted in the plasma and cell volumes in response to the administration of epinephrine, along with other data relating to the cardiovascular system, are shown in Table I and Figure 1. Within approximately 11 minutes after the injection of the drug, there was a decrease in the plasma volume in all instances except two (G. M. and C. H.), in which the volume remained essentially the same. From this point until the termination of the experiment (45 minutes after the administration of epinephrine) the plasma volume gradually diminished, so that 17 to 24 minutes after the drug, the average decrease in plasma volume was $125 \mathrm{cc}$. or 4.1 per cent.

Fairly consistent changes were observed in the cell volume. Increases in cell volume were noted 


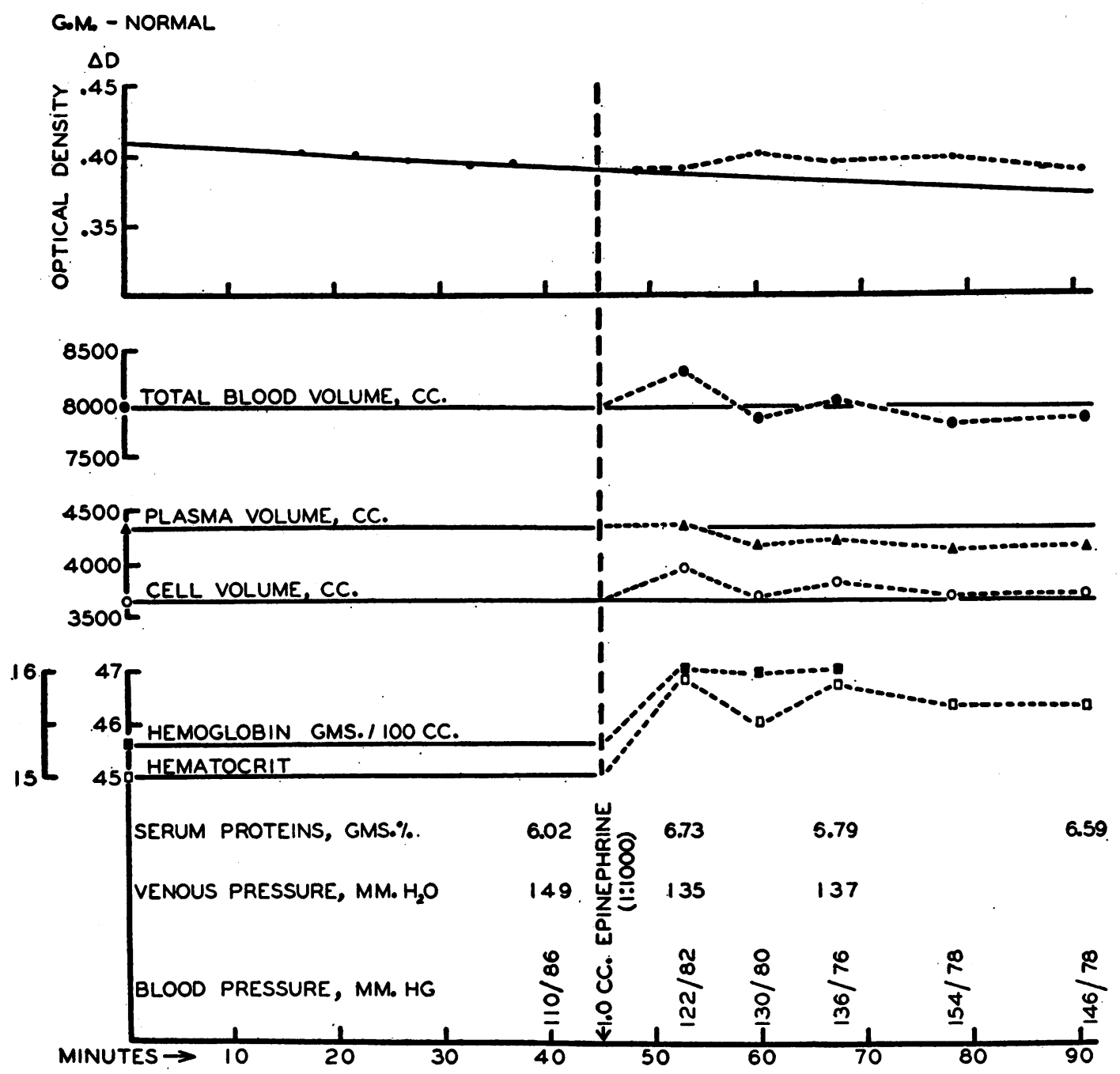

Fig. 1. The Changes in the Volume of the Blood and Other Related Circulatory Measurements Before and After the Subcutaneous Injection of Epinephrine in a Normal Subject

in 4 cases, while in 2 instances there were no significant changes (F. G. and W. P.). The increase in the cell volume was observed shortly after the injection. The gain in volume amounted to as much as $300 \mathrm{cc}$. Following the initial rise, the usual course was a gradual decrease in the cell volume so that, at the end of the experimental period, the average increase was only about onefourth of the initial rise. Part of the increase in cell volume was due to an increase in the leukocytes.

The alterations in the blood volume were variable, since they were dependent upon the relative changes in the cell and plasma volumes. In onehalf of the cases the blood volume was higher than the control value shortly after the injection of epinephrine (6 to 11 minutes). This was due to the rather early marked increase in the cell volume. Following this the blood volume diminished somewhat as a result of the fall in the cell volume. In several cases where the decrease in plasma volume was greater than the increase in cell volume, the blood volume was less than the initial value.

These changes in the volume of the blood were accompanied by an increase in the hemoglobin per unit volume of blood, in the hematocrit, and in the viscosity of the blood. There was a moderate increase in the serum protein concentration. If one assumes that plasma proteins do not enter or 
EPINEPHRINE AND BLOOD VOLUME

TABLE I

Changes in the volume of the blood before and after the subcutaneous administration of epinephrine

\begin{tabular}{|c|c|c|c|c|c|c|c|c|c|c|c|c|c|c|}
\hline & \multirow{2}{*}{$\begin{array}{c}\text { Time } \\
\text { after } \\
\text { injection }\end{array}$} & \multicolumn{6}{|c|}{ Change in volume } & \multirow{3}{*}{$\begin{array}{l}\text { Hemo- } \\
\text { globin }\end{array}$} & \multirow{3}{*}{$\begin{array}{c}\text { Cells } \\
\text { per cent }\end{array}$} & \multirow{2}{*}{$\begin{array}{c}\text { Red } \\
\text { blood } \\
\text { cells }\end{array}$} & \multirow{2}{*}{\multicolumn{2}{|c|}{$\underset{\text { proteins }}{\text { Serum }}$}} & \multirow{2}{*}{ Pulse } & \multirow{2}{*}{$\begin{array}{l}\text { Blood } \\
\text { pressure }\end{array}$} \\
\hline & & \multicolumn{2}{|c|}{ Plasma } & \multicolumn{2}{|c|}{ Cells } & \multicolumn{2}{|c|}{ Blood } & & & & & & & \\
\hline G.R.M. & $\begin{array}{l}\text { minutes } \\
\text { Control }\end{array}$ & $\begin{array}{c}m l . \\
4330\end{array}$ & per cent & $\begin{array}{c}m l . \\
3650\end{array}$ & per cent & $\begin{array}{c}m l . \\
7980\end{array}$ & per cent & & & $\begin{array}{c}\text { per cent } \\
45.2\end{array}$ & $\begin{array}{c}\text { grams } \\
\text { per cent } \\
6.3\end{array}$ & $\begin{array}{c}\text { total } \\
268\end{array}$ & $\begin{array}{c}\text { per } \\
\text { minute } \\
64\end{array}$ & $\begin{array}{l}m m \cdot H_{8} \\
110 / 86\end{array}$ \\
\hline Normal & $\begin{array}{r}8 \\
15 \\
22 \\
34 \\
46\end{array}$ & $\begin{array}{r}+10 \\
-170 \\
-130 \\
-220 \\
-180\end{array}$ & $\begin{array}{l}+0.2 \\
-3.9 \\
-3.0 \\
-5.1 \\
-4.2\end{array}$ & $\begin{array}{r}+300 \\
+20 \\
+150 \\
+40 \\
+50\end{array}$ & $\begin{array}{l}+8.2 \\
+0.5 \\
+4.1 \\
+1.1 \\
+1.4\end{array}$ & $\begin{array}{r}+310 \\
-150 \\
+20 \\
-180 \\
-130\end{array}$ & $\begin{array}{l}+3.9 \\
-1.9 \\
+0.3 \\
-2.3 \\
-1.6\end{array}$ & $\begin{array}{l}16.0 \\
16.0 \\
16.0\end{array}$ & $\begin{array}{l}47.6 \\
46.9 \\
47.5 \\
47.3 \\
47.1\end{array}$ & \begin{tabular}{l|}
46.8 \\
46.1 \\
46.7 \\
46.3 \\
46.3
\end{tabular} & $\begin{array}{l}6.7 \\
6.8 \\
6.6\end{array}$ & $\begin{array}{l}292 \\
285 \\
273\end{array}$ & $\begin{array}{l}78 \\
72 \\
78 \\
82 \\
78\end{array}$ & $\begin{array}{l}122 / 82 \\
130 / 80 \\
136 / 76 \\
154 / 78 \\
146 / 78\end{array}$ \\
\hline W.O. & Control & 3490 & & 2510 & & 6000 & & 13.9 & 41.8 & 41.4 & 6.4 & 223 & 56 & $112 / 66$ \\
\hline Normal & $\begin{array}{l}10 \\
22 \\
30 \\
41\end{array}$ & $\begin{array}{r}-30 \\
-50 \\
-120 \\
-110\end{array}$ & $\begin{array}{l}-0.8 \\
-1.4 \\
-3.4 \\
-3.2\end{array}$ & $\begin{array}{r}+60 \\
+150 \\
+120 \\
+20\end{array}$ & $\begin{array}{l}+2.4 \\
+6.0 \\
+4.8 \\
+0.8\end{array}$ & $\begin{array}{r}+30 \\
+100 \\
0 \\
-90\end{array}$ & $\begin{array}{c}+0.5 \\
+1.7 \\
0 \\
-1.5\end{array}$ & $\begin{array}{l}14.3 \\
14.4\end{array}$ & $\begin{array}{l}42.6 \\
43.6 \\
43.8 \\
42.8\end{array}$ & $\begin{array}{l}41.9 \\
43.1 \\
43.0 \\
42.2\end{array}$ & $\begin{array}{l}6.3 \\
6.3 \\
6.5 \\
6.4\end{array}$ & $\begin{array}{l}218 \\
217 \\
219 \\
216\end{array}$ & $\begin{array}{l}68 \\
68 \\
67 \\
70\end{array}$ & $\begin{array}{l}104 / 68 \\
114 / 72 \\
128 / 50 \\
128 / 52\end{array}$ \\
\hline C.H. & Control & 2680 & & 2670 & & 5350 & & 16.4 & 49.9 & 48.9 & 7.4 & 198 & 75 & $113 / 83$ \\
\hline Normal & $\begin{array}{l}12 \\
24 \\
34 \\
47\end{array}$ & $\begin{array}{l}+20 \\
-80 \\
-60 \\
-20\end{array}$ & $\begin{array}{l}+0.7 \\
-3.0 \\
-2.2 \\
-0.7\end{array}$ & $\begin{array}{r}+150 \\
+100 \\
-30 \\
+10\end{array}$ & $\begin{array}{l}+5.6 \\
+3.7 \\
+1.1 \\
+0.4\end{array}$ & $\begin{array}{r}+170 \\
+20 \\
-90 \\
-10\end{array}$ & $\begin{array}{l}+3.2 \\
+0.4 \\
-1.7 \\
-0.2\end{array}$ & $\begin{array}{l}16.9 \\
16.8\end{array}$ & $\begin{array}{l}51.1 \\
51.5 \\
50.1 \\
50.2\end{array}$ & $\begin{array}{l}50.8 \\
49.5 \\
49.6 \\
49.6\end{array}$ & $\begin{array}{l}7.8 \\
7.4 \\
7.2 \\
7.1\end{array}$ & $\begin{array}{l}211 \\
192 \\
189 \\
189\end{array}$ & $\begin{array}{l}76 \\
78 \\
76 \\
82\end{array}$ & $\begin{array}{l}120 / 78 \\
120 / 76 \\
120 / 74 \\
124 / 72\end{array}$ \\
\hline F.G. & Control & 2490 & & 2310 & & 4800 & & & 48.1 & 47.3 & 7.8 & 194 & 96 & $130 / 80$ \\
\hline Normal & $\begin{array}{r}7 \\
11 \\
16\end{array}$ & $\begin{array}{l}-130 \\
-160 \\
-170\end{array}$ & $\begin{array}{l}-5.2 \\
-6.4 \\
-6.8\end{array}$ & $\begin{array}{l}+30 \\
-10 \\
-20\end{array}$ & $\begin{array}{l}+1.3 \\
-0.4 \\
-0.9\end{array}$ & $\begin{array}{l}-100 \\
-170 \\
-190\end{array}$ & $\begin{array}{l}-2.1 \\
-3.5 \\
-4.0\end{array}$ & & $\begin{array}{l}49.9 \\
49.7 \\
49.7\end{array}$ & $\begin{array}{l}48.9 \\
49.1 \\
48.8\end{array}$ & $\begin{array}{l}8.0 \\
7.8 \\
7.8\end{array}$ & $\begin{array}{l}189 \\
182 \\
181\end{array}$ & $\begin{array}{l}100 \\
102 \\
104\end{array}$ & $\begin{array}{l}170 / 70 \\
165 / 70 \\
165 / 70\end{array}$ \\
\hline J.C.F. & Control & 3030 & & 2250 & & 5280 & & & 42.6 & 42.0 & 6.9 & 209 & 64 & $110 / 78$ \\
\hline Normal & $\begin{array}{l}11 \\
17 \\
27\end{array}$ & $\begin{array}{l}-130 \\
-130 \\
-130\end{array}$ & $\begin{array}{l}-4.3 \\
-4.3 \\
-4.3\end{array}$ & $\begin{array}{r}+80 \\
+110 \\
+80\end{array}$ & $\begin{array}{l}+3.6 \\
+4.9 \\
+3.6\end{array}$ & $\begin{array}{l}-50 \\
-20 \\
-50\end{array}$ & $\begin{array}{l}-0.9 \\
-0.4 \\
-0.9\end{array}$ & & $\begin{array}{l}44.5 \\
44.9 \\
44.5\end{array}$ & $\begin{array}{l}43.7 \\
43.9 \\
43.5\end{array}$ & $\begin{array}{l}7.0 \\
7.3 \\
7.0\end{array}$ & $\begin{array}{l}203 \\
212 \\
203\end{array}$ & $\begin{array}{l}74 \\
72 \\
70\end{array}$ & $\begin{array}{l}118 / 67 \\
126 / 54 \\
132 / 54\end{array}$ \\
\hline W.P. & Control & 3120 & & 2320 & & 5440 & & 13.9 & 42.6 & 42.2 & 7.1 & 222 & 82 & $128 / 90$ \\
\hline $\begin{array}{l}\text { Rheumatoid } \\
\text { arthritis }\end{array}$ & $\begin{array}{r}6 \\
16 \\
27\end{array}$ & $\begin{array}{r}-50 \\
-190 \\
-210\end{array}$ & $\begin{array}{l}-1.6 \\
-6.1 \\
-6.7\end{array}$ & $\begin{array}{l}-30 \\
+20 \\
-40\end{array}$ & $\begin{array}{l}-1.3 \\
+0.9 \\
-1.7\end{array}$ & $\begin{array}{r}-80 \\
-170 \\
-250\end{array}$ & $\begin{array}{l}-1.5 \\
-3.1 \\
-4.6\end{array}$ & $\begin{array}{l}14.2 \\
14.3\end{array}$ & $\begin{array}{l}42.7 \\
44.4 \\
43.8\end{array}$ & $\begin{array}{l}42.4 \\
43.9 \\
42.5\end{array}$ & $\begin{array}{l}7.3 \\
7.3 \\
7.0\end{array}$ & $\begin{array}{l}224 \\
214 \\
204\end{array}$ & $\begin{array}{l}108 \\
112\end{array}$ & $\begin{array}{l}136 / 84 \\
150 / 80 \\
172 / 82\end{array}$ \\
\hline W.D. & Control & 3750 & & 3250 & & 7000 & & 14.1 & 46.4 & 45.5 & 6.1 & 229 & & $136 / 96$ \\
\hline $\begin{array}{l}\text { Polycythemia } \\
\text { vera }\end{array}$ & $\begin{array}{r}5 \\
11 \\
18 \\
20\end{array}$ & $\begin{array}{r}-90 \\
-210 \\
-220 \\
-230\end{array}$ & $\begin{array}{l}-2.4 \\
-5.6 \\
-5.9 \\
-6.1\end{array}$ & $\begin{array}{r}+240 \\
+120 \\
+50 \\
+60\end{array}$ & $\begin{array}{l}+7.4 \\
+3.7 \\
+1.5 \\
+1.8\end{array}$ & $\begin{array}{r}+150 \\
-90 \\
-170 \\
-170\end{array}$ & $\begin{array}{l}+2.1 \\
-1.3 \\
-2.4 \\
-2.4\end{array}$ & $\begin{array}{l}15.0 \\
14.7\end{array}$ & $\begin{array}{l}48.8 \\
48.8 \\
48.3 \\
48.4\end{array}$ & $\begin{array}{l}47.5 \\
47.5 \\
47.0 \\
47.1\end{array}$ & $\begin{array}{l}6.4 \\
6.3\end{array}$ & $\begin{array}{l}227 \\
220\end{array}$ & & $\begin{array}{l}168 / 94 \\
148 / 82 \\
142 / 86 \\
138 / 80\end{array}$ \\
\hline J.D. & Control & 4820 & & 3790 & & 8610 & & 11.6 & 44.0 & 41.7 & 6.6 & 318 & 60 & $110 / 74$ \\
\hline $\begin{array}{l}\text { Polycythemia } \\
\text { vera }\end{array}$ & $\begin{array}{r}8 \\
28 \\
35 \\
40\end{array}$ & $\begin{array}{l}-110 \\
-380 \\
-330 \\
-380\end{array}$ & $\begin{array}{l}-2.3 \\
-7.9 \\
-6.9 \\
-7.9\end{array}$ & $\begin{array}{l}+210 \\
+450 \\
+580 \\
+450\end{array}$ & $\begin{array}{r}+5.5 \\
+11.9 \\
+15.3 \\
+11.9\end{array}$ & $\begin{array}{r}+100 \\
+70 \\
+250 \\
+70\end{array}$ & $\begin{array}{l}+1.2 \\
+0.8 \\
+2.9 \\
+0.8\end{array}$ & 12.2 & $\begin{array}{l}45.9 \\
48.8 \\
49.3 \\
48.8\end{array}$ & $\begin{array}{l}43.1 \\
44.9 \\
44.9 \\
43.8\end{array}$ & $\begin{array}{l}6.8 \\
6.6 \\
6.7\end{array}$ & $\begin{array}{l}302 \\
296 \\
297\end{array}$ & $\begin{array}{l}68 \\
76 \\
80 \\
80\end{array}$ & $\begin{array}{l}110 / 74 \\
114 / 60 \\
118 / 70 \\
118 / 70\end{array}$ \\
\hline R.N. & Control & 3160 & & 2465 & & 5625 & & 13.5 & 43.8 & 42.5 & 6.4 & 202 & 78 & $121 / 73$ \\
\hline $\begin{array}{l}\text { Normal with } \\
\text { splenectomy }\end{array}$ & $\begin{array}{l}11 \\
31\end{array}$ & $\begin{array}{l}-200 \\
-440\end{array}$ & $\begin{array}{r}-6.3 \\
-13.9\end{array}$ & $\begin{array}{r}-45 \\
-185\end{array}$ & $\begin{array}{l}-1.8 \\
-7.5\end{array}$ & $\begin{array}{l}-245 \\
-625\end{array}$ & $\begin{array}{r}-4.4 \\
-11.1\end{array}$ & 14.4 & $\begin{array}{l}45.0 \\
45.6\end{array}$ & $\begin{array}{l}43.5 \\
44.3\end{array}$ & 7.4 & 201 & $\begin{array}{l}72 \\
80\end{array}$ & $\begin{array}{l}124 / 70 \\
138 / 58\end{array}$ \\
\hline D.S. & Control & 3990 & & 3530 & & 7520 & & & 46.9 & 46.0 & 6.6 & 263 & 68 & $130 / 90$ \\
\hline $\begin{array}{l}\text { Normal with } \\
\text { splenectomy }\end{array}$ & $\begin{array}{l}12 \\
21 \\
28\end{array}$ & $\begin{array}{l}-240 \\
-215 \\
-220\end{array}$ & $\begin{array}{l}-6.0 \\
-5.4 \\
-5.5\end{array}$ & $\begin{array}{r}-170 \\
-105 \\
-60\end{array}$ & $\begin{array}{l}-4.8 \\
-3.0 \\
-1.7\end{array}$ & $\begin{array}{l}-410 \\
-320 \\
-280\end{array}$ & $\begin{array}{l}-5.5 \\
-4.3 \\
-3.7\end{array}$ & & $\begin{array}{l}47.3 \\
47.6 \\
47.9\end{array}$ & $\begin{array}{l}46.3 \\
46.9 \\
47.0\end{array}$ & $\begin{array}{l}6.9 \\
6.7 \\
6.8\end{array}$ & $\begin{array}{l}259 \\
253 \\
256\end{array}$ & $\begin{array}{l}90 \\
96 \\
82\end{array}$ & $\begin{array}{l}140 / 90 \\
150 / 80 \\
154 / 94\end{array}$ \\
\hline
\end{tabular}



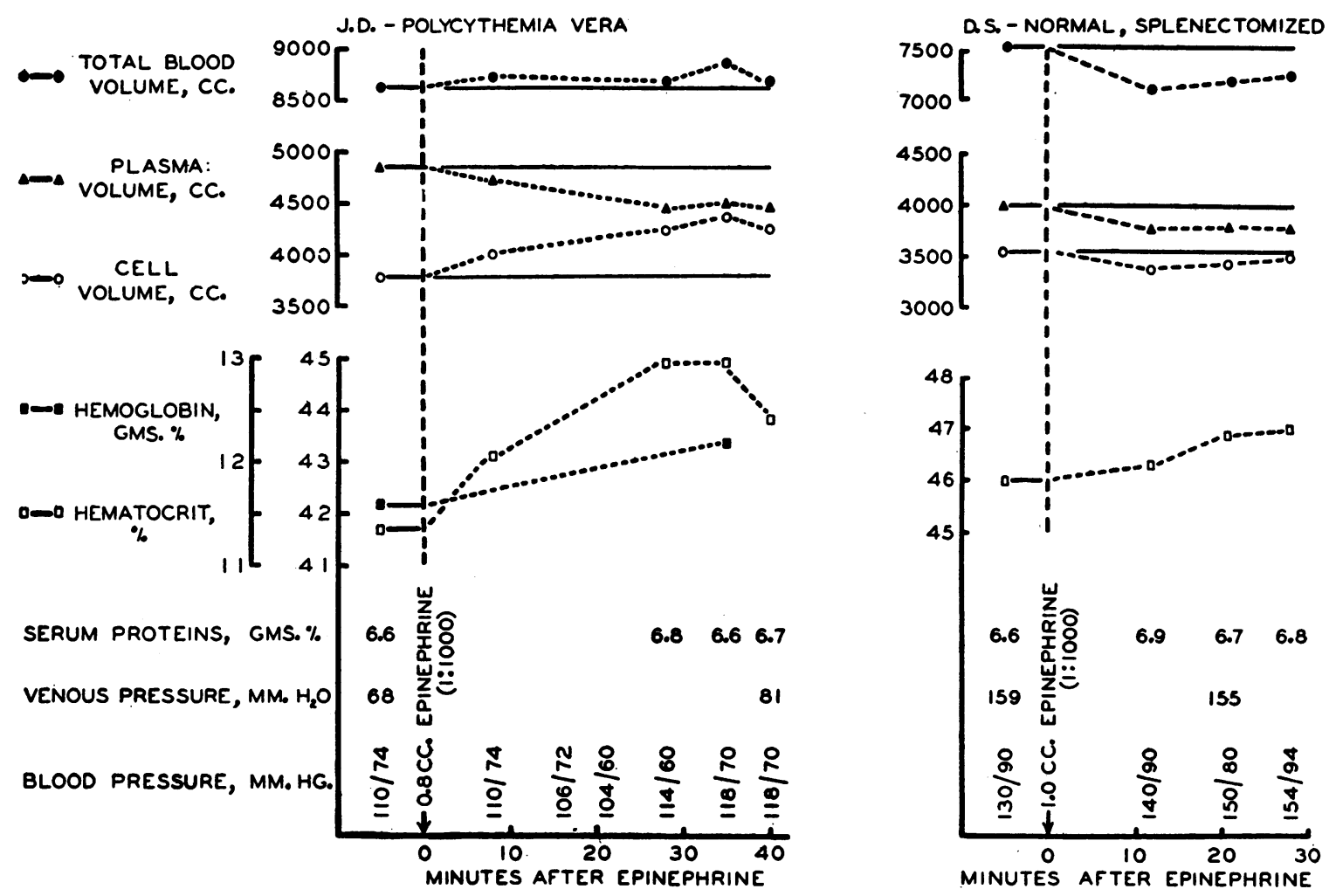

Fig. 2. Changes in the Volume of the Blood Before and After the Administration of Epinephrine in a Subject with Polycythemia Vera (J. D.) and in a Normal Individual who was Splenectomized (D. S.)

leave the circulating blood during this procedure, the changes in plasma volume during the experimental period can be calculated from the values of the serum proteins. The results thus obtained are in fair accord with those observed directly by the dye method. The changes in the total serum protein following the injection of epinephrine, herein demonstrated, are probably not significant. The changes are so small as to be well within the experimental limit of error of both the plasma volume and serum protein techniques.

In addition, these subjects exhibited the well known reactions of the cardiovascular system to epinephrine. The skin became pale, many complained of palpitation, headache, and a "jittery feeling". Between 24 and 46 minutes after the injection, at the height of the reaction, the level of the systolic arterial pressure was elevated in all cases; and the diastolic pressure fell in all the subjects. The pulse rate increased in all instances. The circulation time was shortened in all subjects in which it was determined. The venous pressure rose after the injection in 3 of the 5 cases.
Polycythemia vera. The changes in the blood volume following the administration of epinephrine in $\mathbf{2}$ individuals with polycythemia are illustrated in Table I and Figure 2. The initial values of the blood volume in these two cases illustrate the characteristic changes which take place when this condition is treated by venesection, as they have been repeatedly observed in this laboratory. In untreated cases of polycythemia the cell volume is markedly increased while the plasma volume remains normal, resulting in a high ratio of cells to plasma. During treatment by venesection, as the cell volume falls the plasma volume gradually increases, thereby tending to maintain a relatively high blood volume with the ratio of cells to plasma assuming a normal relationship. After repeated phlebotomies have been done, microcytosis and hypochromia develop, resembling the changes which take place in the erythrocytes in the anemias due to iron deficiency (2).

Shortly after the administration of epinephrine, there was a moderate decrease in the plasma volume which persisted for the duration of the ex- 
periment. At the same time, large volumes of red cells were added to the circulating blood resulting in a slight increase in blood volume in one case (J. D.) and a slight decrease in the other (W. D.). Leukocytes were also added to the blood stream. In one case (J. D.), 35 minutes after the injections, $190 \mathrm{cc}$. of the $390 \mathrm{cc}$. increase in cell volume was due to white blood cells. In both cases at the height of the reaction the spleen was much smaller, and in one case it was no longer palpable. Coincident with these changes, the venous and arterial pressures rose in both cases, and there was concentration of hemoglobin and serum proteins.

Splenectomized subjects. The changes in the blood volume, following the injection of epinephrine in 2 subjects who were previously splenectomized, are illustrated in Table I and Figure 2. Their response was similar to that noted in the normal individuals, except that no new cells were added to the circulation. Actually the cell volume diminished after epinephrine.

\section{DISCUSSION}

It is generally known that the effect of emotional excitement or epinephrine on the peripheral blood is a rise in the number of red blood cells. The mechanism by which this erythrocytosis is brought about has not been definitely decided. There are three possible means, $(a)$ addition of red blood cells to the circulating cell volume, $(b)$ a diminution in the fluid constituents of the blood, or (c) a combination of these two. A perusal of the literature in reference to the volume of the blood and its components after the administration of epinephrine does not throw any light upon the question, for there is no uniformity as to the results. Following the injection of epinephrine in normal individuals, Wollheim (3) and Brandt (4), employing the dye method, observed a marked increase in both plasma and cell volumes, while Levin (5) in 80 per cent of the cases found a decrease in the plasma volume, and an increase in the blood and cell volumes in half of the cases. More consistent results were found when the carbon monoxide method was used. One group (6) observed an increase in the cell and blood volumes in all cases, while another investigator (7) found an increase in the cell volume in two- thirds of the cases. Brednow (8) employing both methods, but neither simultaneously nor in the same subjects, noted an increase in cell volume with the carbon monoxide method and a decrease in the plasma and blood volumes when determined by the injection of dye. In the presence of splenomegaly (leukemia, polycythemia), epinephrine consistently produced an increase in the circulating cell volume when the volume was measured by either the dye or the carbon monoxide method $(9,6,7)$, while in normal individuals in whom the spleen had been removed, there was no appreciable change in the cell volume (6).

The discrepancies in the results obtained by previous investigators and the rather consistent ones obtained by Ebert and Stead (10a), and by us, are due mainly to certain errors inherent in the techniques previously employed. The advantages of the present method may be summarized as follows: ample time is allowed for the mixing of dye and plasma before the experimental period is started; the determination of the plasma volume is independent of the circulatory rate; and, instead of injecting a second dose of the dye during the experimental period, changes in plasma volume following the injection of adrenalin can be calculated from the initial plasma volume, and the deviation in dye concentration from the prolongation of the disappearance slope. Recently Ebert and Stead (10b) called attention to an error in measuring by the indirect method of Gibson and Evans (11) the changes in plasma volume after exercise. This error was due to a change in the optical density of the dye-free serum. In severe or exhaustive exercise they found that as much as 40 per cent of the change in optical density attributed to an increase in dye concentration was actually due to a change in the optical density of the serum. We have repeated such experiments employing the Bausch \& Lomb Spectrophotometer, and found that immediately after exhaustive exercise there is an increase in the optical density of the serum. Ten minutes after the termination of the exercise the optical density of the dye-free serum had returned to its initial value. In moderate exercise, we have not been able to detect any change in the optical density of the serum. In 6 experiments we have not been able to demonstrate a change in the optical 
density of the dye-free serum after the injection of epinephrine. Since the optical density of the dye-free serum at times may increase after the injection of epinephrine, it is wise to consider these changes in the plasma volume as trends rather than precise, quantitative measurements (10a).

In all cases investigated of both normal and abnormal subjects there was a definite diminution in the plasma volume. This persisted in most instances throughout the experimental period. The rise of arterial pressure in man, after epinephrine, represents the combined effects of vasoconstriction in the skin and splanchnic areas, plus cardiac stimulation and vasodilatation in muscles, while constriction of the veins produces a rise in venous pressure. Both tend to diminish the capacity of the vascular system, and simultaneously, plasma volume.

In any discussion of the total cell volume, as measured by the dye method, it is important to realize that the volume is obtained indirectly from the plasma volume and the percentage of cells. The indications are that red cells and the plasma are not uniformly mixed within the vascular system. It has been demonstrated by Ebert and Stead (10c) that in normal subjects the cell plasma ratio varies widely throughout different parts of the circulatory system. What effect the administration of epinephrine, with its varied action on the different segments of the vascular system, may have on this relationship between cells and plasma, it is difficult to surmise. Therefore, too much reliance cannot be placed on the changes in cell volume given above. It appears from these results, that normal subjects add a few cells to the circulating blood volume; those with enlarged spleens add a somewhat larger quantity of cells to the circulation; while splenectomized individuals show a slight loss of cells following the administration of epinephrine. This difference in response can be further shown by the reaction of the blood volume to epinephrine in 2 individuals of the same body build. Both of these individuals (G. M. and D. S.) were heavy and muscular, with large surface areas and large blood volumes. One (G. M.), a normal individual, increased his cell volume after epinephrine, while the other (D. S.), a splenectomized individual, lost cells from the circulation following the injection of this drug. These data simply show the trend of the changes in the total cell volume; they do not prove the point that erythrocytes either leave or enter the blood stream following the administration of epinephrine. Our results substantiate those of others $(10 \mathrm{a}, 12,13)$ which indicate that the spleen of man does not serve as an important reservoir for cells as it does in certain laboratory animals, and that under such conditions as exercise, fever, and hemorrhage, the redistribution of blood within the vascular system is a far more important compensatory reaction than contraction of the spleen.

There is a striking similarity between the effect of severe exercise on the blood volume and the response of the blood to epinephrine (1). In both circumstances there is a hemoconcentration due in part to a shift of a moderate amount of fluid, poor in protein, from the vascular system to the interstitial compartment, and in part to the accession of a small quantity of new cells from the blood depots. The former is produced by increased capillary pressure, while the latter is mediated through the symphatic-adrenin mechanism.

\section{SUMMARY AND CONCLUSIONS}

Measurements were made at rest of the volume of the blood and its components, and variations in the volumes were followed after the subcutaneous injection of $1 \mathrm{cc}$. of epinephrine (1-1000). Further observations included measurements of the blood hemoglobin and viscosity, serum proteins, venous and arterial pressures, velocity of the blood, and pulse rate. These observations lead to the following conclusions:

1. In normal individuals, following the administration of epinephrine, there is a prompt and definite decrease in the plasma volume, which persists in most cases for at least $\mathbf{4 5}$ minutes. In the majority of cases there is a slight increase in the cell volume. These alterations are associated with an increase in blood hemoglobin and viscosity and serum proteins. Following the administration of the drug, the systolic pressure increased while the diastolic pressure fell slightly.

2. In individuals who have polycythemia vera with splenomegaly, epinephrine causes a definite 
decrease in the plasma volume, a moderate increase in cell volume with little change in the total volume.

3. After the injection of epinephrine into 2 individuals whose spleens had been removed, there was a decrease in both blood and plasma volumes, accompanied by a slight decrease in the cell volume.

4. The effects of severe exercise and of epinephrine on the components of the blood volume are similar.

\section{BIBLIOGRAPHY}

1. Kaltreider, N. L., and Meneely, G. R., The effect of exercise on the volume of the blood. J. Clin. Invest., 1940, 19, 627.

2. Stephens, D. J., and Kaltreider, N. L., The therapeutic use of venesection in polycythemia. Ann. Int. Med., 1937, 10, 1565.

3. Wollheim, E., Die zirkulierende Blutmenge und ihre Bedeutung für Kompensation und Dekompensation des Kreislaufs. Ztschr. f. klin. Med., 1931, 116, 269.

4. Brandt, F., Die Abhängigkeit des Venendruckes von der Grösse der zirkulierenden Blutmenge, zugleich ein Beitrag zur Frage seiner klinischen Bedeutung. Ztschr. f. klin. Med., 1931, 116, 398.

5. Levin, E., La acción de la adrenalina sobre el volumen de la sangre circulante. Rev. méd. del Rosario., 1935, 25, 255.

6. Yang, C. S., and Chang, H. C., Effect of adrenalin on circulating blood volume in individuals with normal and enlarged spleens and after splenectomy. Chinese J. Physiol., 1930, 4, 21.
7. Hitzenberger, K., and Tuchfeld, F., Uber den Einfluss des Adrenalins auf die zirkulierende Blutmenge. Klin. Wchnschr., 1929, 8, 1208.

8. Brednow, W., Beeinflussung der zirkulierenden Blutmenge und der Blutverteilung durch physikalische und pharmakologische Massnahmen. Einfluss von Adrenalin, Pituitrin und Histamin. Ztschr. f. d. ges. exper. Med., 1931, 78, 177.

9. Grunke, W., Einfluss des Adrenalins auf die kreisende Plasma-und Blutmenge bei chronischer Milzvergrösserung. Ztschr. f. klin. Med., 1934, 127, 542.

10. (a) Ebert, R. V., and Stead, E. A., Jr., Demonstration that in normal man no reserves of blood are mobilized by exercise, epinephrine, and hemorrhage. Am. J. Med. Sci., 1941, 201, 655.

(b) Ebert, R. V., and Stead, E. A., Jr., An error in measuring changes in plasma volume after exercise. Proc. Soc. Exper. Biol. and Med., 1941, 46, 139.

(c) Ebert, R. V., and Stead, E. A., Jr., Demonstration that the cell plasma ratio of blood contained in minute vessels is lower than that of venous blood. J. Clin. Invest., 1941, 20, 317.

11. Gibson, J. G., 2nd, and Evans, W. A., Jr., Clinical studies on the blood volume. I. Clinical application of a method employing the azo dye "Evans Blue" and spectrophotometer. J. Clin. Invest., 1937, 16, 301.

12. Dill, D. B., Talbott, J. H., and Edwards, H. T., Studies in muscular activity. VI. Response of several individuals to a fixed task. J. Physiol., 1930, 69, 267.

13. Keys, A., and Taylor, H., The behavior of the plasma colloids in recovery from brief severe work and the question as to the permeability of the capillaries to proteins. J. Biol. Chem., 1935, 109, 55. 